\title{
Mervân b. Ebî Hafsa ve Methiyeleri
}

\author{
Muhammed Alanko* (iD) Cüneyt Maral **
}

\begin{abstract}
Atıf/C: Alanko, Muhammed, Maral, Cüneyt, Mervân b. Ebî Hafsa ve Methiyeleri, Artuklu Akademi, 2021/8 (2), 400-411
Öz: Erken dönemlerden itibaren şair, Araplar açısından önemli bir konumda olmuştur. Bu bağlamda ticaretin can damarı sayılan panayırlarda şairler boy ölçüşmüşlerdir. Bunun yanında kabul gören şiirlerin Kâbe duvarına asılması bu eylemin dini hüviyete bürünmesini sağlamıştır. Kabilelerin rekabetinde de şairler aktif rol almış ve kaba kuvvet kadar etkili olmuşlardır. Bu mücadelede övgü ve yergi had safhada kullanılagelmiştir. Övgü temalı şiirler zamanla methiye türünün ortaya çıkmasını sağlamıştır. Mervân b. Ebî Hafsa da Emevî ve Abbâsî döneminde birçok devlet adamına methiyeler yazan ve yazdığı methiyeler sayesinde büyük bir servet sahibi olan önemli Arap şairlerindendir. Mervân, sahip olduğu bu büyük servete rağmen diğer şairler gibi savurgan bir hayat yaşamamış, bilakis elde ettiği serveti aşırı bir cimrilikle korumaya çalışmıştır. Üstün zekâsı sayesinde Abbâsî halifelerinin ilgisini cezbeden şair, özellikle Abbâsî valisi Ma'n b. Zâide için nazmettiği beyitleriyle ön planda olmuştur. Bu makalede Mervân b. Ebî Hafsa'nın hayatından kısaca bahsedilmiş ve methiyeleri ele alınmıştır.
\end{abstract}

Anahtar Kelimeler: Arap Dili ve Belagati, Mervân b. Ebî Hafsa, Şiir, Medih, Abbâsîler, Ma'n b. Zâide.

\section{Marwan ibn Abi Hafsa and His Eulogy on Caliphates}

Citation/@: Alanko, Muhammed, Maral, Cüneyt, Marwan ibn Abi Hafsa and His Eulogy on Caliphates, Artuklu Akademi, 2021/8 (2), 400-411.

\begin{abstract}
From the early times, the poet has occupied an essential position for the Arabs. In this context, the poets competed in the fairs, which used to be considered the lifeblood of trade. In addition, the attachment of the accepted poems on the wall of the Kaaba, which was an important place in the belief system, enabled this action to take on a religious identity. Poets took an active role in the competition of different tribes and they were as effective as military strength. In this tribal struggle, too, praise and obloquy genres were utilized immensely. Praise-themed poems led to emergence of the type of eulogy over time. Marwan bin Abi Hafsa is a significant Arabian poet who wrote praises for lots of statesmen in Umayyad and Abbasid periods and saved a remarkable wealth with these praises. Marwan did not spend a wasteful life like the other poets, even though he had a big fortune, he tried to keep his wealth with an overly stinginess. He became prominent especially with his couplets written for Abbasids governor Ma'n ibn Za'ida. In this article, biography of Marwan ibn Abi Hafsa is briefly referred and his writings in praise/eulogy genre are analyzed.
\end{abstract}

Keywords: Arabic Language and Rhetoric, Marwân b. Abî Hafsa, Poem, Eulogy, Abbasids, Ma'n b. Zấida.

\section{Giriş}

Şair ve şiir, Arapların kültürel yapısının ayrılmaz bir parçası olarak tarih boyunca toplumsal hafızalarında yer edinmiştir. Câhiliye döneminde şairler, toplumun çoğunluğu tarafından rahiplere eşdeğer konumda kabul edilmiş doğaüstü yetenekleri olan kişiler olarak görülmüşlerdir. Şairler panayırlarda bireyleri konu edindikleri gibi kabilevî yapıları da konu edinen şiirleri dile getirmişlerdir. Hatta bazı kabileler kılıç ve kaba kuvvetin yanında şairlerin sivri dilleriyle mücadele etmekteydiler. Bu bağlamda kabileler, karşılıklı mücadelelerini şairlerini de yanlarına alarak hakemlerin huzuruna çıkıp sürdürmüşlerdir. Şairler de övgü ve yergi içerikli şiirleriyle kabilelerini savunmaktaydılar. ${ }^{1}$

Araplarda övgü çok önemli olup asabiyet sistemi içerisinde önemli bir yer edinmektedir. İnsan tabiatı gereği övülmek ve takdir edilmek ister. Erken dönemlerden itibaren Araplarda birey ve toplum psikolojisinde övünme ve böbürlenme had safhadaydı. Yaşadığ1 yere göre herkes kendini üstün görmekteydi. Örneğin köyde ve şehirde oturan kişi çölde yaşayanı küçümserdi. Şehirli bir tüccar, kendi statüsünde olmayanlardan uzak dururdu. Buna karşın çölde yaşayan bir bedevi de kendini bütün iyiliklerin, güç ve yiğitliğin sahibi görürdü. Câhiliye şairi kabilesinin toprağı, vadisi, işi ve geçim kaynağı ile övünürdü. Bunu yaparken düşman kabileyi de yererdi. Şair çölde yaşayan bir bedevi ise güçlü kişinin işinden saymadığı ziraat, zanaat ve ticaret gibi işlerle uğraşmayı küçümserdi. Bunlarla meşgul olanları korkudan

\footnotetext{
* Yüksek Lisans Öğrencisi, Batman Üniversitesi Lisansüstü Eğitim Enstitüsü, alanko_21@hotmail.com

Dr. Öğr. Üyesi, Batman Üniversitesi İslami İlimler Fakültesi, Arap Dili ve Belegatı Anabilim Dalı, cuneytmaral21@gmail.com

Yahya Suzan, Di'bil ve Hicivleri (Ankara: Sonçağ, 2017), 1.
} 
savaşmayıp bir köşeye çekilen zayıf kimseler olarak görürdü. ${ }^{2}$ Toplumda övme vazifesini yüklenen şairler genellikle asabiyet bağı çerçevesinde bağlı bulundukları kabileyi yüceltme maksadıyla övgüleri sıralamayı amaç edinirken Câhiliye sonrası dönemde maddi menfaat, sosyal ve siyasal konumlar elde etmek için bu eylemi icra etmişlerdir.

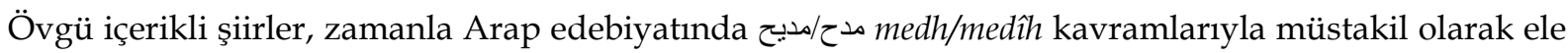

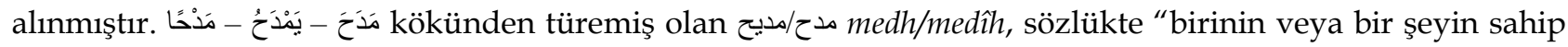
olduğu güzel meziyetleri dile getirmek, birinden veya bir şeyden memnuniyet duymak, övmek, senâ etmek" anlamlarına gelmektedir. ${ }^{3}$ Edebî anlamda hicvin zıddı olan medih için tek bir tanım yapmak zor görünmektedir. Medih için "kişinin aklı, cesareti, iffeti, adaleti ile övülmesidir bunların dışındaki övgü medih değildir" ve "kişinin taşıdığı ya da sonradan kazandığı iyi özelliklerle övülmesidir" şeklinde sınırlayıcı ve sınırı tam konamayan tanımlar yapılmıştır. ${ }^{4}$ Övgünün edebî üsluba bürünmüş hali olan medih için genel olarak şunları ifade etmek mümkündür: "Medih, birine karşı takdir ve şükran duygularını sunmak veya maddi bir çıkar elde etmek gayesiyle daha çok bireysel olmakla birlikte kabile, toplum, millet, ülke, vatan, şehir vb.nin güzel sıfat ve meziyetlerini dile getirmektir. Bu içerikteki şiirlere de methiye denmiştir." 5 Methiyenin tarihsel seyrine bakıldığında ise Câhiliye döneminde bu konuda müstakil kasidelerin bulunmadığı göze çarpmaktadır. Bu dönemde methiyeler gazel, fahriye ve hamriyeler içerisinde yer almıştır. Bu bağlamda methiyelerin sonraki asırlarda müstakil olarak ele alındığı dile getirilmiştir. İçerik açısından da methiyelerin Câhiliye döneminde birey ve kabileye yöneldiği, sonraki aşamalarda ise siyasi erkler, şehirler, halk kitleleri ve fırkalara yöneldiği dikkati çekmektedir. ${ }^{6} \mathrm{Bu}$ değişimin yaşanmasında siyasi yapı ve yaşam şartlarında meydana gelen dönüşümün etkisi göze çarpmaktadır.

Toplum nazarında önemli bir konuma sahip olan Câhiliye şairi, kabilesinin iftihar kaynağı ve düşmanla mücadele aracı olarak görülmekteydi. Şair tipolojisine bakıldığında ise Câhiliye döneminde şairler şarap ve kadınları da konu edinir, başı buyruk bir yaşam sürerlerdi. Halkın teveccühü ve yardımlarıyla ayakta duran şairlerin övdükçe ya da yerdikçe kazanç elde etmeleri, benimsedikleri yaşam tarzının doğal sonucuydu. Bunun yanında şairin övgüsüne mazhar olmak büyük bir paye, yergisine maruz kalmak da en büyük utanç kabul edilirdi. Her ne kadar İslâm'ın zuhuru toplumun ve bireyin bazı yapısal değişimlere uğramasını sağlasa da sonraki dönemlerde Câhiliyeden gelen davranış formları gün yüzüne çıkmıştır. Şairler ve toplumun nazarındaki yerleri de bu bağlamda sonraki dönemlerde önemini korumuştur. Bu aşamadan sonra şairler, menfaat vb. durumlar için methiyeler dizmiş kabile reisinin yerini artık siyasi erk almış ve yönetici konumunda olanlar da şairin toplum üzerindeki etkilerini kullanmaya çalışmışlardır. Mervân b. Ebî Hafsa da Abbâsî döneminde yaşayan ve siyasi erk ile yakın duran şairlerdendir ve dönemin yöneticilerine methiyeler dizerek maddi menfaat elde etme çabasında olmuştur. Mervân b. Ebî Hafsa'nın methiyeleri edebi açıdan önemli olmakla birlikte tarihsel açıdan da yönetici ve şairler arasındaki alakayı ortaya koyması bağlamında önemlidir. Nitekim yönetici erk, şairleri bazen propaganda aracı olarak kullanmıştır. Bu hususlara binaen bu makalede Mervân b. Ebî Hafsa'nın hayatı aktarılacak ardından methiyeleri tarihsel arka planıyla birlikte irdelenecektir. Meşhur bir şair olması ve yaşadığı dönem göz önüne alındığında Mervân b. Ebî Hafsa'nın çok sayıda çalışmaya konu olduğu görülmektedir. ${ }^{7}$ Ancak yapılan çalışmalarda şairin edebi kişiliği ve şiirsel üslubu ön plana çıkmış olup methiyeleri arka planda kalmıştır. Ayrıca genel anlamıla şairin tipolojik yapısı göz ardı edilmiştir. Yine şairlerin davranışsal yapılarında Câhiliye döneminden bahse konu olan zamana kadar meydana gelen değişimler tam anlamıla

\footnotetext{
Yahya Suzan, Arap Siirinde Hiciv (Konya: Aybil, 2012), 1.

İbn Manzûr, Lisânu'l-'Arab (Beyrût: Dâru Sâdır, ts.), "mdh" 2/589; İsmail Durmuş, "Methiye", Türkiye Diyanet Vakfi İslâm Ansiklopedisi (Ankara: TDV Yayınları, 2004), 29/406.

Sa'id Hamid Sevârib, el-Medhufís s-si'ri'l-câhilî (Kahire: Mecmu'a Ecyâlli Hidmâti't-Tesvîk, 2008), 11.

Durmuş, "Methiye", 29/406

Siraceddîn Muhammed, el-Medîhu fî́şs-şi'ri'l-'Arabî (Beyrut: Dâru'r-Râtibi'l-Câmi'îyye, ts.), 6-7.

Kahtan Reşîd et-Temîmî, Mervân b. Ebî Hafsa ve şi'ruhu, (Necef: Matbatu Nu'mân, 1392/1976); Nureddîn Muhammed Zevîn, el-Hasaisu'l-uslübiye fì și'ri, Mervân b. Eb̂̂ Hafsa, (Misır: Cami’atu Menûfiyye, Küliyeti'l-'Âdab, Yüksek Lisans Tezi, 1430/2009); Îmân Mahmud İbrahim Kutub, Medâihu Mervân b. Hafsa fíl-'Abbâsiyyîn (İskenderiyye: Câmi'atu İskenderiyye, Yüksek Lisans Tezi, 2015); Eşref Muhammed 'Alam, "er-Ru'yetü's-siyâsiye fî şi'ri Mervân b. Ebî Hafsa", Havliyâtu Âdâbi 'Ayni Şems 41 ( Eylül 2013), 81-111; Hazım Burhan Alnajjar, "es-Sıdku'l-'atîfî fî şi'ri Mervân b. Ebî Hafsa”, Rumelide Dil ve Edebiyat Araştırmaları Dergisi 23, (Haziran 2021), 731-738.
} 
mukayese edilmemiştir. Bu bağlamda bu çalışmada, Mervân b. Ebî Hafsa üzerinden meydana gelen değişimin analiz edilmesi de hedeflenmiştir.

\section{Hayatı}

Tam adı Mervân b. Süleymân b. Yahyâ b. Ebî Hafsa'dır ancak daha çok Mervân b. Ebî Hafsa olarak bilinir. Hicrî 105, milâdî 723 yılında Yemâme bölgesinde doğmuştur. Oğlunun adı Sımt olması hasebiyle kendisine Ebu's-Sımt künyesi verilmiştir. Nazmettiği bir beyitten ötürü Zu'l-Kiml lakabıyla anılan Mervan, ayrıca Ebu'l-Heyzâm ve Ebu'l-Hendâm künyeleriyle de çağrılmıştır. ${ }^{8}$

Mervân'ın nesebiyle alakalı bir ihtilaf söz konusudur. Bazı ravilere göre, Ebû Hafsa künyesiyle bilinen dedesi Yezîd, Hz. Osman (ö. 35/656) veya Mervân b. el-Hakem (ö. 65/685) vasitasıyla Müslüman olan Yahudi bir doktor idi. Arap kabilelerinden olan 'Ukl kabilesi, Ebû Hafsa'nın kendi kabilelerine mensup olduğunu iddia etmiş ve Yemâme halkı da bu iddianın doğru olduğu konusunda 1srarcı olmuşlardır. Ancak Ebû Hafsa'nın kendisi ve ailesi bu iddiayı kabul etmemişlerdir. Torunu Muhammed b. İdris (ö. ?), ‘Ukl kabilesinin iddiasını reddetmiş ve dedesinin onlardan olmadığını, aksine İran'ın güneyindeki Fars şehirlerinden İstâhr bölgesine mensup bir köle olduğunu ifade etmiştir. Yaygın görüşe göre, torununun belirttiği gibi, Ebû Hafsa fars asıllı olup çocukluk dönemini Ukl kabilesinde geçirmiştir. Daha sonra Hz. Osman onu yanına almış ve ileriki dönemlerde Mervân b. el-Hakem'e hibe etmiştir. Ebû Hafsa, Hz. Osman'ın şehit edildiği gün büyük bir kahramanlık göstererek yaralanan Mervân b. el-Hakem'i savaş ortamından çıkarmayı başarmıştır. Mervân b. el-Hakem, Medine valisi olunca onun bu cesaretini ödüllendirmek maksadıyla kölelikten azat etmiş ve Yemâme haracını toplamak üzere kendisini görevlendirmiştir. ${ }^{9}$

Hicrî 105 yılında Yemâme bölgesinde doğan Mervân'ın buradaki hayatı, çocukluk yılları ve halkla olan ilişkileri hususunda tarih ve edebiyat kitaplarında yeterli bir bilgi bulanmamaktadır. Ancak şairin şiirlerine bakıldığında, henüz yirmili yaşlarda iken Şâm'a geldiği ve Emevî halifelerinden Velîd b. Yezîd'e (ö. 126/744) ödüllerine nail olma ümidiyle şu methiyeleri dizdiği görülmektedir:10

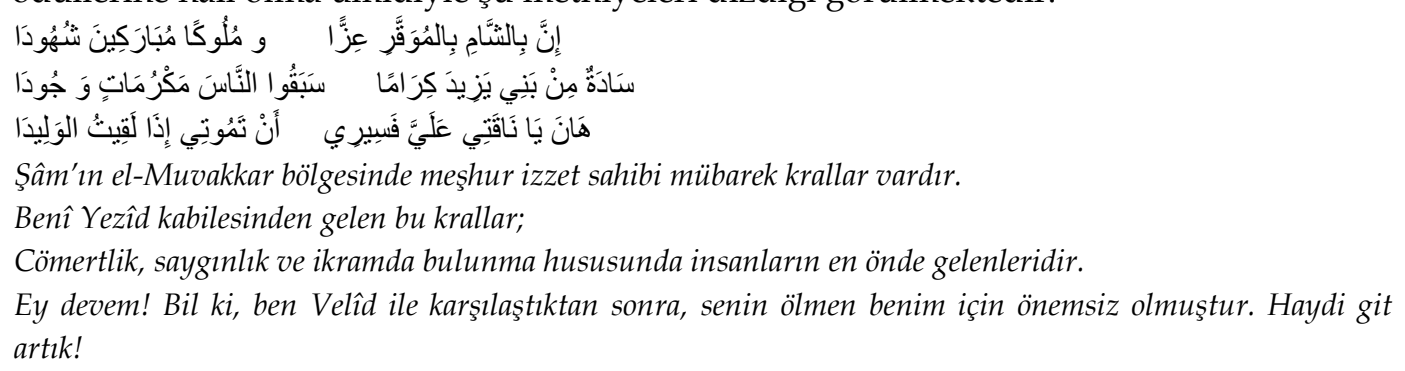

Yazmış olduğu bu beyitler Velîd'in hoşuna gitmemiştir. Bu nedenle şair Velîd'den uzaklaşmış ve artık Emevî halifeleri için şiir nazmetmekten geri durmuştur. Bu durum, onun halifeler yerine Emevî valilerine yönelmesine sebep olmuştur. Şairin daha çok Abbâsî valilerinden Ma'n b. Zâide'yi(ö. 151/768 [?]) öven kasideleri bulunmaktadır. Ma'n vefat ettikten sonra ise Abbâsî halifelerinden Mehdî (ö. 169/785), Hâdî(ö. 170/786) ve Harûn Reşîd'i (ö. 193/809) överek şiirlerine devam etmiştir.11

Mervân, halifelere ve devlet adamlarına methiyeler düzen ve bunun karşllı̆ında ödüller elde eden soylu bir aileden gelmektedir. Kendisi de pek çok halife, vali ve vezir için methiyeler yazmış ve bunun neticesinde büyük bir servet sahibi olmuştur. Mervân ile aynı dönemde yaşayan Arap şairleri onun kadar kazanç sağlayamamışlardır. Ancak $\mathrm{O}$, sahip olduğu bu büyük servete rağmen cimri kişiliğiyle ön planda olmuştur. Öyle ki onun cimriliği yiyecek ve giyeceklerine de bariz bir şekilde yansımıştır. Bir rivayete göre

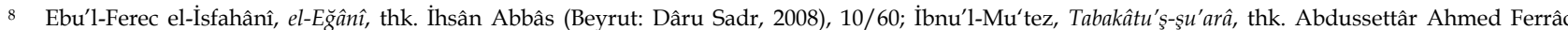
(Kâhire: Dâru'l-Me'ârif, 1976), 42; İbn Hallikân, Vefeyâtu'l-a'yân, thk. İhsân Abbâs (Beyrut: Dâru Sâdır, 1977), 5/189; Mervân b. Ebî Hafsa, Şi'ru Mervân b. Eb̂̂ Hafsa, nşr. Hüseyn Atvân (Kâhire: Dâru'l-Me'ârif, 2009), 7; Süleyman Tülücü, "Mervân b.Ebû Hafsa", Türkiye Diyanet Vakfi İslâm Ansiklopedisi (Ankara: TDV Yayınları, 2004), 29/229.

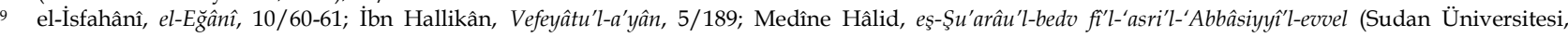
Doktora Tezi, 2015), 77.

10 Mervân b. Ebî Hafsa, Şi'ru Mervân b. Ebî Hafsa, 33

11 Hişâm Abdu's-Selâm Alî Câdd, “Ma'n b. Zâide fî şi'ri Mervân b. Ebî Hafsa: er-ru'ye ve'l-edât”, Mecelletu Külliyeti'l-Âdâb 1/27 (Ocak 2012$)$, 14.
} 
Halife Mehdî, Mervân'a ve dönemin bir diğer şairi Selm el-Hâsır'a(ö. 186/802) ikramda bulunurdu. Selm elHâsır değeri 10 bin olan ve üzerinde süslü eyer ile yular bulunan bir beygirle Mehdî́nin huzuruna gelirdi. Ayrıca ipek kumaştan yapılmış ve pahalı olan elbiseler giyinir, güzel kokular sürerdi. Ancak Mervân b. Ebî Hafsa, Mehdî́nin huzuruna üzerinde; koç derisinden yapılmış bir kürk, kalın bir gömlek, pamuktan bir sarık, ucuz bir terlik ve pis kokulu kalın bir örtü ile gelirdi. ${ }^{12}$

Mervân büyük bir cimrilik ve tamahkârlık ile servet biriktirmeye çalışmışır. Bu nedenle kıt kanaat geçinmiş ve kendini dünyevi lezzetlerden alıkoymuştur. Övdüğü kişilerden elde ettiği serveti kendisi için bile kullanmamaya gayret göstermiştir. Rivayetlere göre bir cemaat, Mervân'ı ziyaret etmek için Yemâme'ye gelir. Mervân kendilerine hurma ikram eder. Ardından hizmetçisine bir miktar para ve bir kap vererek yağ almaya gönderir. Hizmetçi parayı alıp gider. Mervân, kısa bir süre sonra hizmetçinin elinde yağla döndüğünü görünce bir anda sinirlenir. Hizmetçisini karşısına alarak "sen bana ihanet ettin" der. Hizmetçi, Mervân'ın söylemiş olduğu söz karşısında şaşırmış bir şekilde "bu parayla sana nasıl bir ihanette bulunabilirim ki?" diye cevap verir. Ancak Mervan, hizmetçinin yağı birinden ücretsiz talep ettiğini ve parayı cebe attığını söyler. ${ }^{13}$

Bir başka rivayete göre, Mervân et düşkünü biridir. Ne zaman canı et istese, hizmetçisini yanına çağırır ve çarşıya gidip kelle (hayvanın baş kısmı) almasını ister. Kendisine yaz kış niçin kelle yediği sorulduğunda ise, diğer etlere nazaran kellenin fiyatını daha iyi bildiğini, dolayısıyla hizmetçisinin kendisini kandıramayacağını söyler. ${ }^{14}$ Mervân'ın hizmetçisiyle yaşamış olduğu bu iki olaya bakıldığında onun çevresindeki insanlara karşı daima bir kuşku içinde olduğu ve bu insanlar tarafından kandırılma korkusuyla yaşadığı görülmektedir.

Şair, yaşamı boyunca halifeler ve valilerden aldığı ödüllere rağmen diğer şairler gibi savurgan bir hayat yaşamamış, aksine elde ettiği büyük serveti aşırı bir cimrilikle korumaya çalışmışır. Eğlenceden uzak basit bir hayat yaşayan şair, cimri yapısıyla ön planda olmuştur. Dolayısıyla bu yönünü ele alan pek çok rivayetle karşılaşmaktayız. Bu rivayetlerden birine göre Mervân kasaptan yarım dirheme et alır. Aldığı eti pişirmek üzere tencereye bırakır. Ancak o esnada arkadaşlarından biri kendisini yemeğe davet eder. Bunun üzerine neredeyse pişmiş kıvama gelen eti tencereden çıkarıp satın aldığı kasaba eksik bir miktarla geri vermeye çalışır. Bunun üzerine rahatsız olan kasap Mervân'dan şikayetçi olur. Bu durum Hârûn Reşîd'e kadar ulaşır. Hârûn Reşîd Mervân'ı yanına çağırır ve "yazıklar olsun sana, bu yaptığın nedir?" diye azarlar. Mervân, halifenin bu söylemleri üzerine "ben israf yapmayı sevmem" der. ${ }^{15}$

Hayatının büyük bir kısmını Yemâme'de geçiren Mervân'da, yabancı kültürle yoğrulmuş Bağdat Abbâsî kültür ve medeniyetinin etkisine rastlanmamaktadır. Dolayısıyla şiirlerine bakıldığında daha çok çöl şairlerinin gelenekleri ağır basmaktadır. Ayrıca şiirlerinde duygu ve düşüncelerini bir hitap havasında dile getirmesinden ötürü II. yüzyılda ortaya çıkan "minberî şiir" adındaki şiir türünün önde gelen temsilcilerinden sayılmaktadır. ${ }^{16}$

Medih, Mervân bin Ebî Hafsa'nın ihtimam gösterdiği en önemli şiir konusudur. Her ne kadar hiciv, gazel, mersiye ve tasvir alanında şiirler nazmetse de eserlerinin büyük bir kısmını medih üzerine inşa etmiştir. Öte yandan medih alanındaki şiirlerini nazmederken övdüğü kişilerin ilgisini çekerek daha fazla ödüle nâil olmak adına yazmış olduğu beyitler üzerinde bir yıl boyunca uğraştığı kaydedilir. İlgili yılın ilk dört ayında şiiri nazmeder, ikinci dört ayında bu şiir üzerinde düzenlemeler ve süslemeler yapar, son dört ayında ise şiiri bu alandaki usta şair ve eleştirmenlerin incelemelerine sunar. Özenle nazmettiği şiir beğeniler toplarsa bu şiiri övdüğü kişiye ve halka takdim eder. ${ }^{17}$

Mervân b. Ebî Hafsa hicrî 182 milâdî 798 yılında ${ }^{18}$ Hârûn Reşîd döneminde vefat etmiştir. Vefatıyla ilgili kaynaklarda kesin bir bilgi olmamakla birlikte Şia'dan birinin suikastı sonucu öldürüldüğü yönünde

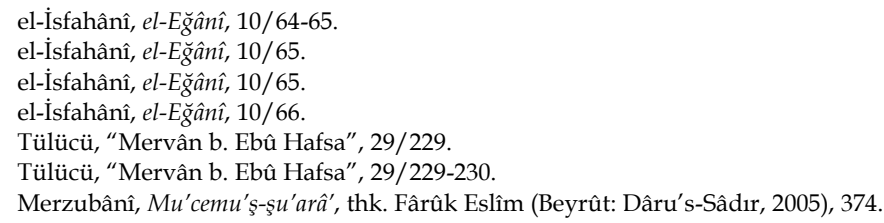


bir iddia söz konusudur. Bu iddiaya göre, Sâlih b. 'Atiyye (ö.?) adındaki bir şahıs, Mervân'ın Şia ile ilgili muhalif görüşlerinden rahatsız olmuş ve kendisinden intikam almaya yemin etmiştir. Bu ahdini gerçekleştirmek için de Mervân'la yalandan dostluk ilişkileri kurmaya çalışmış ve olabildiğince yanından ayrılmamaya gayret göstermiştir. Bu durum Mervân'ın sıtma hastalığına yakalanmasına kadar devam etmiştir. Sâlih b. 'Atiyye, Mervân'ın hasta olduğu bu dönemlerde daha fazla yanında olmaya çalışmıştır. Nitekim bir gün baş başa kalma fırsatı yakalayan Sâlih, Mervân'ı boğazlayarak öldürmüştür. ${ }^{19}$

\section{Methiyeleri}

Mervân b. Ebî Hafsa, gerek Emevî döneminde gerekse Abbâsî döneminde, karşılaştığı halifelere ve önemli mevki sahibi şahsiyetlere ödüllerine nâil olma ümidiyle methiyeler dizmiştir. Hayatının erken dönemlerinde şiir yazmaya başlayan Mervân, öncelikle Emevî halifesi Velîd'i metheden beyitler inşâd etmiş fakat halife beklentilerine cevap vermeyince, büyük bir hayal kırıklığı ile memleketi Yemâme'ye geri dönmüştür. Nitekim şairin şiirlerine bakıldığında Emevî dönemine ait şiirleri oldukça azdır. O daha çok Abbâsî döneminde başta Abbâsî valisi Ma'n b. Zâide olmak üzere dönemin halifelik görevini icrâ eden şahsiyetlerine methiyeler yazmaya gayret göstermiştir. Bu çalışmada öncelikle Mervân'ın Ma'n b. Zâide ve Abbâsî Halifeleri için nazmettiği dönemin siyasal çalkantılarına da ışık tutan bazı methiyelerine yer verilecektir.

\subsection{Emevî Komutanı ve Abbâsî Valisi Ma'n b. Zâide'ye Methiyeleri}

Ebû Müslim el-Horâsânîye ait isyancı bir grup, Abbâsî halifesi Ebû Ca'fer el-Mansûr'un Hâşimiyye'deki sarayını kuşatmıştı. Az sayıda askeriyle hazırlıksız bir şekilde yakalanan Ebû Ca'fer elMansûr, neredeyse bu isyancı grup tarafından öldürülecekti. Halifenin ölüm tehlikesiyle karşı karşıya kaldığını fark eden Ma'n b. Zâide eş-Şeybânî, yüzleri örtülü muhafızlar arasından sıyrılarak halifenin önüne geldi ve onu isyancıların elinden kurtarmayı başardı. Bu cesurluğuyla yetinmeyen Ma'n b. Zâide halife saraydan çıkarken onun atının yularını tutarak canını tehlikeye attı. Halife, kendisi için kahramanca savaşan bu askeri merak etmiş ve sonrasında bu askerin güçlü bir kabileden gelen Ma'n b. Zâide olduğunu öğrenince onu takdir ederek Yemen valiliğine tayin etmiştir. ${ }^{20}$

Ma'n b. Zâide halifenin kendisini mükâfatlandırdığı bu makam sayesinde, Yemen bölgesinde büyük bir şöhrete ulaşmıştır. Dolayısıyla bir çok şair, Ma'n b. Zâide' nin ödülüne nail olmak için onu öven kasideler yazmışlardır. Bu durum Yemâme'de bulunan Mervân b. Ebî Hafsa'nın da ilgisini cezbetmiştir. Mervân Yemen'e gelerek Arap medhinin harika örneklerinden sayılan kasideleriyle Ma'n'ı övmeye başlamıştır. Bu kasideler, şairin Ma'n b. Zâide tarafından ödüllendirilmesinin yanı sıra büyük bir şöhret elde etmesine de yol açmıştır.

Araplar daima nesepleriyle iftihar eden bir kavimdir. Geride bıraktıkları edebî kültürde bu durumu açık bir şekilde görmek mümkündür. Şairler şiirlerinde övgülerine mazhar olan kişilerin neseplerinden iyi bir şekilde bahsetmeye gayret göstermişlerdir. Şair Mervân b. Ebî Hafsa da Ma'n b. Zâide'yi överken daima onun güzel ahlakından ve faziletlerinden bahsetmekte ve bu ahlakın onun soyuyla bağlantılı olduğuna vurgu yapmaktadır. Ma'n b. Zâide' deki ahlakın hem kendisinde hem de kavminde sarsılmaz bir konumda olduğuna dikkat çekmektedir. Şair, Ma'n'ın korkak ve yardıma muhtaç kimseler için uğrak noktası olduğunu bir kasidesinde şöyle dile getirmektedir:21

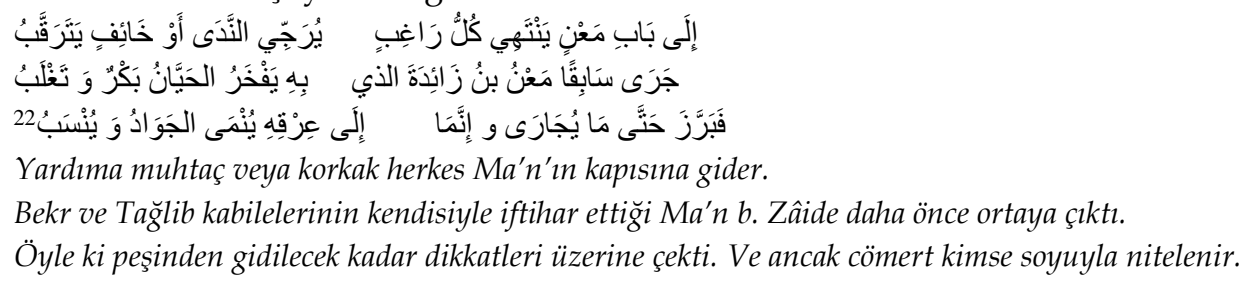

Medîne Hâlid, eş-Şu'arâu'l-bedv fíl-asri'l-'Abbâsî, 84

Mahmut Kelpetin, "Ma'n b. Zâide", Türkiye Diyanet Vakfi İslâm Ansiklopedisi (Ankara: TDV Yayınları, 2019), EK-2 Cilt/191-192.

Hişâm Abdu's-Selâm Alî Câdd, "Ma'n b. Zâide fî şi'ri Mervân b. Ebî Hafsa: er-ru'ye ve'l-edât", 24.

Mervân b. Ebî Hafsa, Şi'ru Mervân b. Ebî Hafsa, 16-17. 
Şair bu beyitlerinde yardıma muhtaç ve korkak insanların Ma'n b. Zâide' nin yanına geldiklerini ve Ma'n'ın bu insanların umutlarını boşa çıkarmamak adına onlara yardım ettiğini ifade etmektedir. Şair, Ma'n'ı cömertlik sıfatıyla övmekte ve bu cömertliğin eski zamanlara dayandığına vurgu yapmaktadır. Öyle ki Bekr ve Tağlib kabileleri Ma'n b. Zâide ile daima övünmüşlerdir.

Mervân en güzel methiyelerini Ma'n b. Zâide'yi överken söylemiştir. Onun için inşad ettiği methiyeler, Abbâsî halifelerinin birçoğunun ilgisini çekmiş ve dolayısıyla Abbâsî halifeleri onun şiirlerini incelediklerinde, şairlerin halifeleri överken söyledikleri kaliteli medih örnekleriyle karşılaşmışlardır. Şairin aşağıda yer alan beyitleri, bahsi geçen şiir türlerinden biridir. Şair, bu beyitlerine Ma'n b. Zâide'nin dördüncü dedesi olan Matar'ı ve onun soyundan gelen evlatlarını överek başlamaktadır:

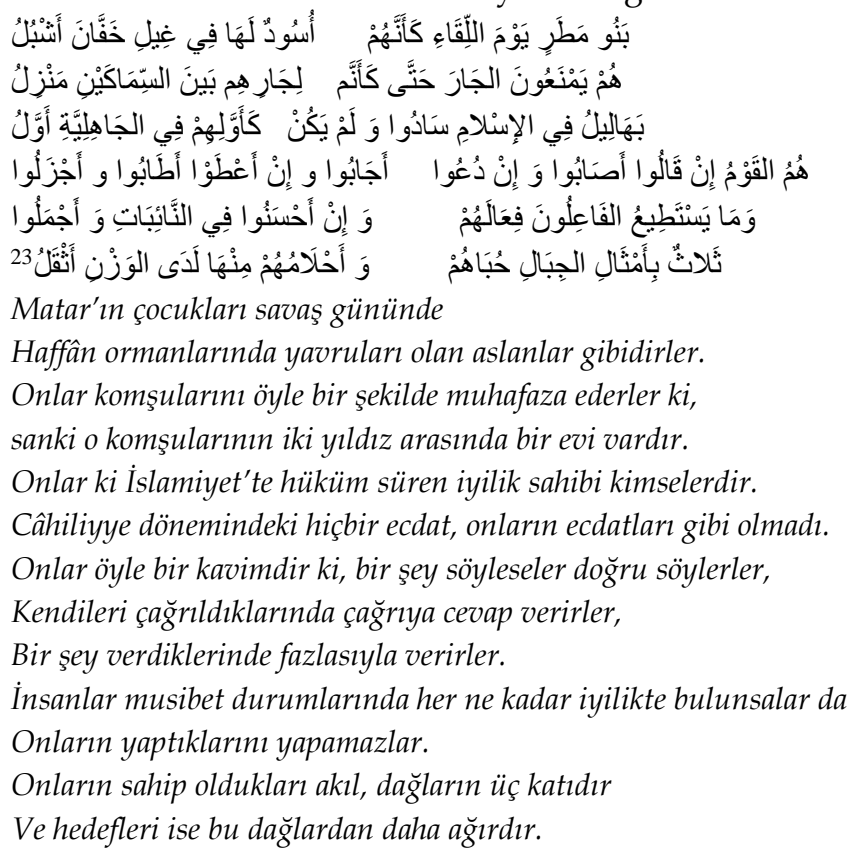

Bu lâmiyye, Mervân'ın Ma'n b. Zâide için söylediği en güzel kasidelerden biri olarak kabul edilmektedir. Zira bazı edebiyatçlar bu kasidenin güzelliğine değinmeden geçmemişlerdir. İbnu'l-Mu'tez, bu kaside için “Mervân'ın yazdığı en güzel kaside, Ma'n b. Zâide'yi överek söylediği lâmiyyedir. Zira bu kaside sayesinde döneminin şairlerine nispeten daha fazla ilgi görmüştür" diyerek şairin yazdığı lâmiyyenin önemine vurgu yapmaktadır. İbnu'l-A'râbî ise bu kaside karşılığında Ma'n'ın Mervân'a verdiği ödüllerin az olduğunu, hatta sahip olduğu her şeyi ona verse dahi onun hakkını ödeyemeyeceğini söylemiştir. ${ }^{24}$

Emevîler döneminde komutanlık görevini icra eden Ma'n b. Zâide, Abbâsîler döneminde Yemen ve Sistân valiliklerine tayin edilmişti. Cesur bir asker olmasının yanı sıra çevresindeki insanlara yaptığı yardımlarla da tanınan Ma' $n, 25$ özellikle Abbâsiler döneminde insanların ilgisini çekmeyi başarmıştı. Sahip olduğu makam ve yaptığı iyilikler neticesinde, birçok şair onun cömertlik vasfını ele alan şiirler nazmetmişlerdi. Bu şairlerin başında Mervân b. Ebi Hafsa geliyordu. Aslında bunda şaşılacak bir durum yok. Çünkü aynı zamanda Ma'n'ın ödüllerine en fazla nail olan şairdir. Bu sebeple Ma'n için yazdığı her kasidede onun cömertlik vasfına değinmiştir:

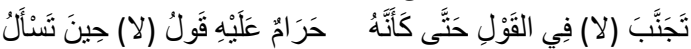

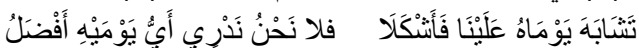

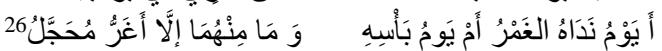

$$
\begin{aligned}
& \text { Ondan bir şey istediğinde "hayır" demekten kaçınır. } \\
& \text { Sanki "hayır" demek, onun için haram bir şeydir. } \\
& \text { İki gününün benzer olması, bizim için anlaşılması güç bir durumdur. }
\end{aligned}
$$

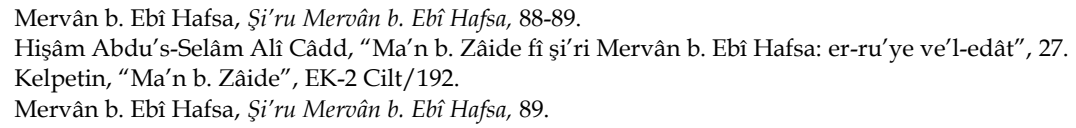


Çünkü hangi gününün daha iyi olduğunu bilmeyiz.

Yardımlarının sel olup aktığı gün mü? Yoksa kahramanca savaştı̆̆ı gün mü?

O iki gün arasında parlak beyaz renkli bir at vardır.

Ma'n b. Zâide, Mervân'ın kendisi için nazmettiği bir kasideyi ona yüz bin dirhem vererek ödüllendirmiştir. Bu durum dönemin halifesi Mansûr'a kadar ulaşmıştır. Nitekim Ma'n b. Zâide bir gün halifenin huzuruna geldiğinde, Halife, Mervan'ın Ma'n için nazmettiği kasideden bir beyti kendisine okur ve Mervân'a yüz bin dirhem vermesine sebep olan beytin bu beyit mi olduğunu sorar:

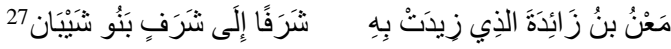

$O$, sayesinde Benû Şeybân kabilesinin şerefinin arttığı Ma'n b. Zâide'dir.

Ma'n, Mervân'ı bu beytinden ötürü ödüllendirmediğini, bilakis şu beyitlerinden ötürü ödüllendirdiğini ifade eder:

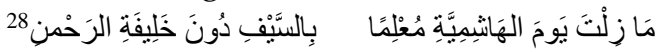

Haşimiyye gününde sen kllı̧ ustası olarak durmadan Rahman'ın halifesinin etrafindaydın.

Daha önce ifade ettiğimiz gibi Ma'n b. Zâide Halife Mansûr'u Hâşimiyye' deki sarayını kuşatan isyancı bir gruba karşı korumuştur. Mervân bu beyitleriyle Ma'n'ın o günkü kahramanlığına vurgu yapmıştır. Dolayısıyla Halife Ma'n'ın Mervân'a bu beyitlerinden ötürü ödül verdiğini duyunca mahcup olur ve ona dönerek yüz bin dirhem vermekle iyi yaptığını dile getirir. ${ }^{29}$

\subsection{Abbâsî Halifelerinden Mehdî̀ye Yönelik Methiyeleri}

Şairin Ma'n b. Zâide üzerine söylediği beyitlerin yanı sıra Abbâsî halifelerine nazmettiği methiyeler de bulunmaktadır. Onun methettiği ilk Abbâsî halifesi Mehdî́dir. Ancak şair ile halifenin ilk görüşmesi farklı bir şekilde vuku bulmuştur. El-Fadl b. er-Rebî'in anlatımına göre Mervân b. Ebî Hafsa, sayesinde büyük servet sahibi olduğu Ma'n b. Zâide vefat ettikten sonra Bağdat'a gelip Abbâsî halifelerinden Mehdî'nin huzuruna çıktı. Bir grup şairin yer aldığı mecliste, yazmış olduğu kasideyi halifeye okudu. Bunun üzerine Halife kendisine dönüp kim olduğunu sordu. Halifenin bu sorusuna cevap olarak "ben senin şairin Mervan b. Ebî Hafsa" dedi. Halife, Mervân'ın daha önce Ma'n b. Zâide için nazmettiği bir beyti hatırlatarak "sen değil misin, Ma'n'dan sonra nereye gideriz diyen? Şimdi de gelmişsin bizden hediyeler talep ediyorsun. Bizim yanımızda sana vereceğimiz hiçbir şey yok" dedi. Sonrasında halifenin adamları Mervân'ı ayaklarından çekiştirerek meclisten dışarıya çıkardılar. ${ }^{30}$ Halifenin bu tavrı karşısında çaresiz bir şekilde memlekete dönen Mervân, Bağdat'a halifenin hediyelerine nail olma ümidiyle gelmiş, ancak halife onun daha önce Abbâsî valilerinden Ma'n için nazmettiği bir beyti eleştirerek kapı dışarı etmişti. Ertesi yıl, yazdığı başka bir kaside ile tekrar halifenin huzuruna çıkmaya karar verdi. Şair, siyasî içerikli bu kasidesinde Abbâsîlerin halifeliğe daha layık olduğunu savunarak halifenin gönlünü kazanmaya çalışmıştır.

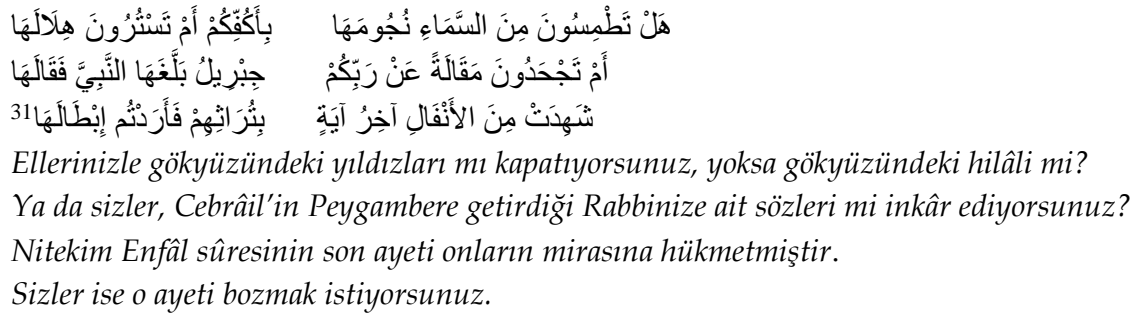

Şair siyasî içerikli bu beyitlerinde, alevîleri muhatap alarak onların Abbâsîlere karşı mücadelelerini eleştirmiş ve Abbâsîlerin hilafetteki haklılı̆̆ını Kur'an'daki Enfâl sûresinin son ayetiyle ispatlamaya çalışmıştır. Nitekim bu ayette geçen ifade şu şekildedir:

\footnotetext{
Mervân b. Ebî Hafsa, Si'ru Mervân b. Ebî Hafsa, 106 .

Mervân b. Ebî Hafsa, Şi'ru Mervân b. Ebî Hafsa, 107.

9 el-İsfahânî, el-Ĕ̆ânî, 10/75.

el-İsfahânî, el-Ĕĝânî, 10/71-72.

Mervân b. Ebî Hafsa, Şi'ru Mervân b. Ebî Hafsa, 99.
} 


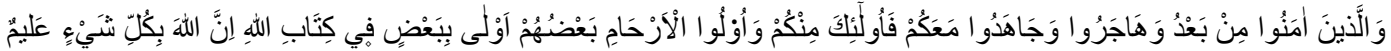
"Sonrasında inanıp hicret eden ve sizinle beraber cihâd edenler, işte onlar sizlerdendir. Allah'ın kitabina göre erham sahipleri (akrabalık bağı olanlar) birbirine daha yakındır. Şüphesiz Allah her şeyi hakkıyla bilendir."

Mervan, Enfâl sûresinde yer alan bu ayeti öne sürerek Abbâsîlerin hilafeti hak ettiğini, onların bu hususta Hz. Fatıma'nın çocuklarından önce hilafeti elde etmeleri gerektiğini ve mirasta amcaların torunlardan önce geldiğini savunmuştur. Halife bu beyitleri işitir işitmez büyük bir hayranlıkla yerinden kalkar ve Mervân'a dönüp nazmettiği kasidenin kaç beyitten oluştuğunu sorar. Mervan yüz beyitten oluştuğunu söyleyince, halife ona yüz bin dirhem verilmesini emreder. ${ }^{32}$

Mervan maddi kazanç elde etme adına her zaman Abbâsî halifeleri ile irtibatını sağlamlaştırmak istemiştir. Bu nedenle bir yandan Abbâsîlerin hilafetteki haklılı̆̆ını savunurken öte yandan Abbâsîlere muhalif olan gruplara ağır eleştirilerde bulunmuştur. ${ }^{33}$ Nitekim Halife Mehdî́ yi överken de onun hilafetteki haklılığını savunmuş ve onu tevazu, takva, insan haklarını gözetme, Allah'a karşı huşu içinde olma gibi bir takım meziyetlerle ön plana çıkarmıştır.

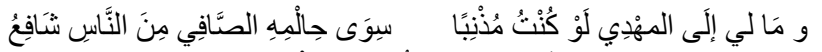

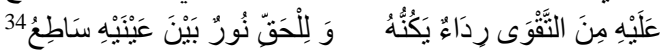

Bir suçlu olsaydım, insanlar arasında tertemiz olan Mehdî́nin affetmesinden başka bir şefaatçi benim için var olmazdl.

Onun üzerinde onu koruyan takvadan bir elbise vardır. Gözlerinin arasında /alnın ortasinda hak nur parlar

Bir rivayete göre Mervân b. Ebî Hafsa halife Mehdî́yi Rusâfe şehrindeki sarayında ziyaret eder. Bu ziyaretinde halife için nazmettiği beyitleri okur. Bunun üzerine halife ona büyük miktarda para verir: 35

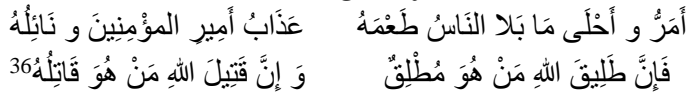

Mervân b. Ebî Hafsa bir gün halife Mehdî'nin yanına Kasru's-Selâma'ya gider. Ya'kûb b. Davud adındaki bir şahsın yaptıklarından ötürü Mehdî'nin öfkeli bir halde oturduğunu görür. Bunun üzerine Mervân, halife Mehdî’ye dönüp söz konusu şahsın Râfizîlere mensup biri olduğunu ve hatta söylemiş olduğu bir beytinden ötürü kendisine düşman olduğunu söyler. ${ }^{37}$

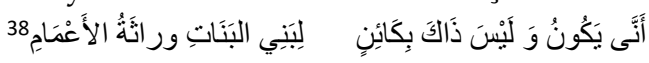

Her ne olursa olsun, amcalarn veraseti kadinların çocuklarna ait olmaz.

Mervân bu beyitlerinde tekrardan Abbâsîlerin hilafetteki haklılığına değinmektedir. Dolayısıyla söz konusu bu beyit, Ya'kûb’un düşmanlığını kazanmasına yol açmıştır. Mervân, Ya'kûb’un kendisine düşman kesilmesine aldırmadan bu beyit dışında birkaç beyit daha okuduğunu halifeye söyler.

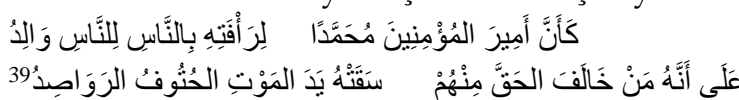

Müminlerin Emiri Muhammed, insanlara karşı merhametli olduğu için

insanlarn babast gibidir. Her ne kadar o insanlar onun hakknna muhalefet etseler ve puslu ölümler ona ölüm

eli uzatsalar da.

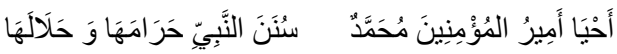

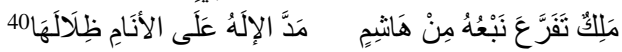

Müminlerin Emiri Muhammed (Mehdî), Peygamberin sünnetindeki helal ve haram olan şeyleri yaşattl.

Onun kaynağı, Allah'ın insanlara gölgesini uzattığı Hâşim'den olan bir kraldır.

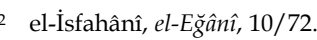

Mervân b. Ebî Hafsa, Şi'ru Mervân b. Ebî Hafsa, 66.

el-İsfahânî, el-Ĕ̆ân̂î, 10/73.

Mervân b. Ebî Hafsa, Si'ru Mervân b. Ebî Hafsa, 95.

el-İsfahânî, el-Ĕ̆ânî̀, 10/73.

8 Mervân b. Ebî Hafsa, Şi'ru Mervân b. Ebî Hafsa, 104

Mervân b. Ebî Hafsa, Si'ru Mervân b. Ebî Hafsa, 38.

Mervân b. Ebî Hafsa, Şi'ru Mervân b. Ebî Hafsa, 97.
}

3 Mustafa eş-Sek'a, Rıhletu's-si'r, (Kâhire: Ed-Dâru'l-Misriyyetu'l-Lubnaniyye, 1997), 514 
Mervân'ın bu beyitleri halife Mehdî’nin hoşuna gitmiş ve halife kendi cebinden 30 bin dirhem vermiştir. Bununla yetinmeyerek ona bir cübbe ve bir şal hediye etmiştir. ${ }^{41}$

\subsection{Abbâsî Halifelerinden Mûsâ el-Hâdî'ye Yönelik Methiyeleri}

Mervân'ın Mehdî dışında övdüğü bir diğer Abbâsî halifesi Mûsâ el-Hâdî’dir. Onunla ilgili havadisleri oldukça azdır. Çünkü aralarında çok fazla bir münasebet olmadan Hâdî vefat etmiştir. Aralarında kısa süreli bir irtibat olmasına rağmen Mervân'ın Hâdî üzerine yazmış olduğu methiyeden yola çıkılarak bu irtibatın güçlü bir boyutta olduğu söylenebilir.

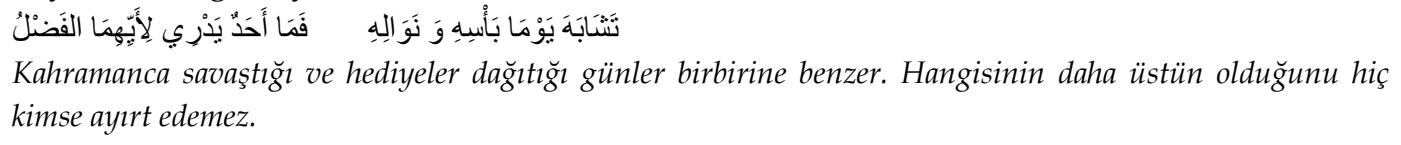

Bu beyit üzerine Hâdî, Mervân'a dönerek "peşin verilen 30 bin dirhemi mi yoksa hazineye ait hesap defterlerine sana verilmek üzere kaydedilen 100 bin dirhemi mi istersin?" şeklinde bir soru yöneltir. Mervân, halifenin sorusuna "Ey Müminlerin Emiri, hangisinin daha iyi olduğunu sen bilirsin. Ancak şu an bunu unutmuşsun. İzin verirsen sana hatırlatayım" şeklinde cevap verir. Halife de onun bu isteğini tamam diyerek kabul eder. Bunun üzerine Mervân kendine 30 bin dirhemi peşin ödeyeceğini, diğer 100 bin dirhemi de kendisine verilmek üzere hazineye ait hesap defterine yazacağını söyler. Bu cevap karşısında Hâdî "bilakis hepsi peşin verilecek" diyerek bütün ödülü peşin vermiştir. ${ }^{42}$

\subsection{Abbâsî Halifelerinden Hârûn Reşîd'e Yönelik Methiyeleri}

Mervân, Abbâsî halifelerinden Hârûn Reşîd için de methiyeler kaleme almıştır. Yazdığı bu beyitler incelendiğinde, onun her zamanki gibi övdüğü kişilerin ödüllerine nail olmayı amaçladı̆̆ı ve bu amaç doğrultusunda bir takım göndermeler yaptığ1 görülmektedir:

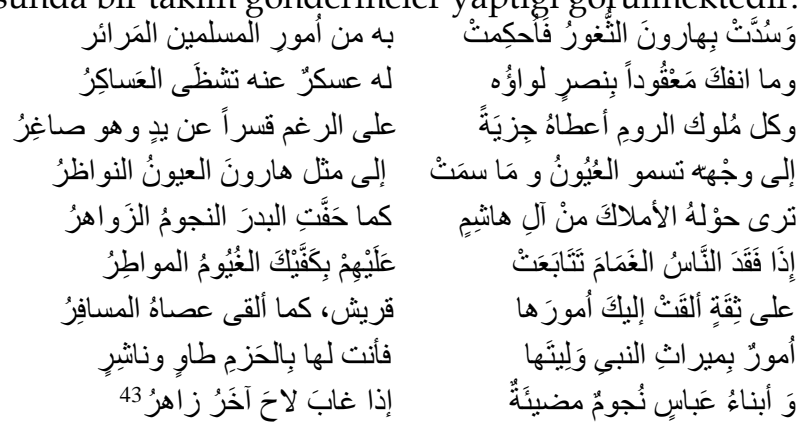

Hârun ile gedikler kapandı. Müslümanlar acılara karşı muhkem oldu.

Onun sancă̆ı daima yardıma bağlıdır. Onun öyle bir askeri vardır ki diğer askerler onun karşısında parçalanır.

Rum krallarının tümü kendi elleriyle ona cizye vermesine rağmen o kibirlenmez.

Gözler onun yüzüne yöneliyor. Bakan gözlerin hiç biri onun gibisine yönelmemiştir.

Parlak yıldızların ayın etrafinı sardığı gibi Haşimî ailesinin önde gelenlerini onun etrafinda görürsün. İnsanlar yağmur dolu bulutlarn yitirdiğinde yă̆mur dolu bulutlar senin avuçlarıla onları takip eder.

Yolcunun değneğine dayandığı gibi Kureyşliler senin güvenilirliğine dayanıp

İşlerini sana teslim ettiler.

O işleri Peygamber'den miras aldin ve sen azim ile onları koruyor ve yayıyorsun.

43 Mervân b. Ebî Hafsa, Şi'ru Mervân b. Ebî Hafsa, 53; Muhammed b. Cerîr et-Taberî, Târîhu'r-rüsüli ve'l-mülûk, thk. Muhammed Ebu'l-Fadl İbrahim (Kahire: Dârü'l-Me'ârif, ts.), 8/347-348. 
Abbâs'ın çocukları ışık saçan yıldızlar gibidirler. Bir yıldız kaydı̆̆ında onun yerine daha parlă̆ı gelir.

Bir kısmı aktarılan söz konusu methiyelerde, daha önceki halifelere dizdiği methiyelerde olduğu gibi Mervân, hilafetin Abbâsîlerin hakkı olduğunu Hârûn Reşîd'in Hz. Peygamber'den hilafeti miras aldığını vurgulamıştır. Bunun yanında yağmur metaforunu da kullanıp teşbihte mübalağaya gidip Hârûn Reşîd'in doğa üstü olaylara müdahale ettiğini dile getirmiştir. Bu methiyeleri duyan Hârûn Reşîd çok sevinir Mervân'a bir cübbe giydirip beş bin dinar ve on tane Rum köle verip kendi özel bineğiyle onu göndermiştir. ${ }^{44}$

\section{Sonuç}

Arap edebiyatının temel taşı olan şiir, Arapların kültürel, sosyal ve siyasi yapılarından izler taşımaktadır. Şairlerin taşıdığı tarihi verilere odaklanmak, Arapların anlam dünyasına inebilmeyi kolaylaştıracaktır. Kabilevi yapıya bağlı asabiyet eksenli yaşam tarzının hüküm sürdüğü bir coğrafyada övgü ve yergi had safhada olmuştur. Kabileler şairler üzerinden mücadele ederken şairler onların mal varlıklarından istifade etmişlerdir. Toplumsal ahlak haline gelen bu karşılıklı iletişim daha sonraki dönemlerde de devam etmiştir. Değişim sadece aktörlerde meydana gelmiştir. Artık şair yeni toplumsal ve siyasal duruma ayak uydurmuş, yeni düzenin aktörleri de şairin toplumdaki konumunu kullanarak propagandalarını sürdürmüşlerdir.

Hicrî 2. yüzyılda hem Emevî hem de ilk Abbâsî dönemini yaşamış olan Mervân b. Ebî Hafsa da şiirleriyle ön plana çıkan bir Arap şairidir. Her ne kadar mersiye, hiciv, gazel gibi şiir türlerine ait beyitleri bulunsa da, kendisi daha çok halifelerin ve devlet adamlarının -ödüllerine nail olma ümidiyle- övdüğü methiyeleriyle tanınmıştır. Yazdı̆̆ı şiirlerle Emevîler döneminde pek ilgi görmeyen şair, Abbâsîler döneminde, Abbâsîlerin halifelikte daha evlâ olduğunu dile getirdiği şiirleri sayesinde dönemin halifelerinin ilgisini çekmeyi başarmış ve bu halifelerin ödüllerini kazanmıştır. Gerek Abbâsî valisi Ma'n b. Zâide'ye gerekse Abbâsi halifelerine nazmettiği beyitler, okuyucuya şiirsel bir haz vermektedir. Bunun yanı sıra methiyelerinde halifelikle ilgili siyasî konulara değinmesi hasebiyle dönemin siyasî havasını da yansitmaktadir.

\section{Kaynakça}

'Alam, Eşref Muhammed. "er-Ru'yetü's-siyâsiye fî şi'ri Mervân b. Ebî Hafsa”. Havliyâtu Âdâbi 'Ayni Şems 41 (Eylül 2013), 81-111.

Ebu'1-Ferec el-İsfahânî, Alî b. el-Huseyn b. Muhammed b. Ahmed el-Kureşî. el-Ĕğânî, thk. İhsân Abbâs. Beyrut: Dâru Sâdır, 2008.

Hazım Burhan Alnajjar. “es-Sıdku'l-'atîfî fî şi'ri Mervân b. Ebî Hafsa, Rumeli'de Dil ve Edebiyat Araştırmaları Dergisi 23, (Haziran 2021), 731-738.

Hişâm Abdu's-Selâm Ali Câdd. “Ma'n b. Zâide fî şi'ri Mervân b. Ebî Hafsa: er-ru'ye ve'l-edât”, Mecelletu Külliyeti'l-Âdâb, 1/27 (Ocak 2012), 3-72.

İbn Hallikân, Ahmed b. Muhammed b. Ebî Bekr. Vefeyâtu'l-a'yân ve enbâu ebnâi'z-zaman, thk. İhsân 'Abbâs. Beyrût: Dâru Sâdır, 1977.

İbnu'l-Mu'tez, Ebu'l-'Abbâs 'Abdullâh b. Muhammed el-Mu'tezz. Tabakâtu'ş-şu'arâ, thk. Abdussettâr Ahmed Ferrâc. Kâhire: Dâru'1-Me'ârif, 1976.

İbnu'n-Nedîm, Ebû'l-Ferec Muhammed b. Ebî Ya'kûb İshâk b. Muhammed b. İshâk. el-Fihrist. Beyrut: Dâru'l-Ma'rife, 2013.

Kelpetin, Mahmut. "Ma'n b. Zâide". Türkiye Diyanet Vakfi İslâm Ansiklopedisi. EK-2 Cilt/191-192. Ankara: TDV Yayınları, 2019.

\footnotetext{
44 Taberî, Târîhu'r-eüsüli ve'l-mülûk, 8/347-348.
} 
Kutub, Îmân Mahmud İbrahim. Medâihu Mervân b. Hafsa fíl-'Abbâsiyyîn. İskenderiyye: Câmi'atu İskenderiyye, Yüksek Lisans Tezi, 2015.

Medîne Hâlid. eş-Şu'arâu'l-bedv fíl-asri'l-'Abbâsî. Sudân Üniversitesi, Doktora Tezi, 2015.

Mervân b. Ebî Hafsa, Mervân b. Süleymân b. Yahyâ b. Ebî Hafsa Yezîd. Şi'ru Mervân b. Ebî Hafsa. nşr. Hüseyin Atvân. Kâhire: Dâru'l-Me'ârif, 2009.

Merzubânî, Ebû Ubeydillâh Muhammed b. İmrân b. Mûsâ b. Saîd. Mu'cemu'ş-şu'arấ'. thk. Fârûk Eslîm. Beyrût: Dâru's-Sâdr, 2005.

Mustafa eş-Şek'a. Rıhletu'ş-şi'r. Kâhire: ed-Dâru'l-Mısriyyetu'l-Lubnaniyye, 1997.

Sa'id Hamid Şevârib. el-Medhu fi'ş-şi'ri'l-câhilî. Kahire: Mecmu'a Ecyâlli Hidmâti't-Tesvîk, 2008.

Sirâceddîn Muhammed. el-Medîh fíş-şi'ri'l-'Arabî. Beyrut: Dâru'r-Râtibi'l-Câmi'îyye, ts.

Suzan, Yahya. Arap Şiirinde Hiciv. Konya: Aybil, 2012.

Suzan, Yahya. Di'bil ve Hicivleri. Ankara: Sonçă̆, 2017.

et-Taberî, Muhammed b. Cerîr. Târîhu'r-rüsüli ve'l-mülûk. thk. Muhammed Ebu'l-Fadl İbrahim, Kahire: Dârü'l-Me'ârif, ts.

et-Temîmî, Kahtan Reşîd. Mervân b. Ebî Hafsa ve şi'ruhu. Necef: Matbatu Ne’amân: 1392/1976.

Tülücü, Süleyman. "Mervân b. Ebû Hafsa". Türkiye Diyanet Vakfi İslâm Ansiklopedisi. 29/229-230. Ankara: TDV Yayınları, 2004.

Zevîn, Nureddîn Muhammed. el-Hasaisu'l-üslubiye fí şi'ri, Mervân b. Ebî Hafsa. Misır: Cami'atu Menûfiyye, Külliyeti'l-'Âdâb, Yüksek Lisans Tezi, 1430/2009. 
Doi: 10.34247/artukluakademi.1008852 | Araştırma Makalesi

\title{
Muhammed Alanko (iD Cüneyt Maral
}

\author{
Marwan ibn Abi Hafsa and His Eulogy on Caliphates
}

Citation/C: Alanko, Muhammed, Maral, Cüneyt, Marwan ibn Abi Hafsa and His Eulogy on Caliphates, Artuklu Akademi, 2021/8 (2), 400-411.

\section{Extended Abstract}

Poet and poetry, as an integral part of cultural structure of the Arab, have taken a specific place in their social memories throughout history. In the period of Jahiliyyah, poets were seen as people with supernatural abilities who were accepted as equivalent to priests by the majority of the society. The tribes maintained their bilateral struggles, taking their poets with them, before the arbiters. Poets were also defending their tribes with their poems characterized with praise and satires. Humans naturally want to be praised and appreciated. Praise is a very important phenomenon among Arabs and it has an important place in tribalism. The poet class in Jahiliyyah period was proud of his tribe's land, valley, work and livelihood. While doing so, he would also slander the enemy tribe. While the poets who took on the duty of praising in the society generally aimed to rank the praises in order to glorify the tribe they belonged to within the framework of the ties of tribalism, they performed this duty in order to obtain material benefits, social and political prestiges in the post- Jahiliyyah period. As a result of these expectations, the type of praise which is basically defined as expressing beautiful attributes and virtues of a tribe, society, nation, country, homeland, city, etc. has a place in literary field with the aim of expressing feelings of appreciation and gratitude towards someone or gain a material benefit. In terms of content, it is noteworthy that eulogies were directed to individuals and tribes in the age of Jahiliyyah and in the later stages, they were directed to political powers, cities, masses of people and sects. The effect of the transformation in the political structure and living conditions in this change is striking.

Within terms of content, it is remarkable that eulogies were directed to individuals and tribes in the Age of Jahiliyyah and in the later stages they were directed to political powers, cities, masses of people and sects. The effect of the transformation in the political structure and living conditions in this change is striking. In this context, it is seen that the praising genre underwent a change in terms of content and the poet tried to take a place next to the state dignitaries in the new order and to cover the praising with a political form.

Marwan ibn Abi Hafsa was one of the famous poets who witnessed some parts of the Umayyad and Abbasid periods. Marwan ibn Abi Hafsa wrote many poems during his lifetime. In his poems, the type of eulogy makes one feel the weight of the political power of his period. Therefore, his praises are of political content. He especially praised the Abbasids on their right to attain the power of caliphate. However, as we look at the poems of the poet, it is seen that he arranged the eulogies for Walid ibn Yazid (d. 126/744) that was one of the Umayyad caliphs in the hope of achieving his rewards when he came to Damascus but the couplets he wrote did not please Walid. Therefore, the poet distanced himself from Walid and refrained from composing poetry for Umayyad caliphs. This situation caused him to turn to Umayyad governors instead of caliphs. In addition, there are eulogies praising one of the Abbasid governors, Ma'n ibn Za'ida (d. 151/768 [?]). After Ma'n passed away, he continued his poems by praising the Abbasid caliphs Mahdi (d. 169/785), Hadi (d. 170/786) and Harun al-Rashid (d. 193/809). In return for these praises, he received awards and had a great fortune. However, despite his great wealth, he was at the forefront with his stingy personality. Biography of Marwan who spent most of his life in Yamama, does not reflect the influence of Baghdad Abbasid culture and civilization mixed with foreign culture. When we look at his poems, the traditions of desert poets predominate. In addition, due to the way of expressing his feelings and thoughts in an air of address, he is considered to be one of the leading representatives of the poetry genre called "minbari poetry" which emerged in the 2nd century. In his eulogies about his Ma'n, the poet generally praises him in view of his generosity and emphasizes that this generosity dates back to ancient times. In his political eulogies to the Abbasid caliphs, the poet criticizes their struggle against the Abbasids by addressing the ideology of that day and in some couplets he tries to prove the rightness of the Abbasids in the caliphate with the last verse of Surah al- Anfal in the Qur'an.

As a result, it is fair to say that the the poetry, which is the cornerstone of Arabic literature, carries the traces of the cultural, social and political structures of the Arab. Focusing on the historical data carried by the poets will make it easier to descend into the conceptual premises of the Arabic community. In addition, the eulogies positioned themselves in the tribal order as a link to the social structure during the Jahiliyyah period and integrated themselves into the state system in the new order in terms of both the praised addressee and the purpose, they focused on political/theological conflicts. This change was at the content level. The sedentary personality traits of poets continued as inherited behaviors. Marwan ibn Abi Hafsa also embraced this hereditary behavior and presented the eulogies to the service of the ruling authority. 